Research Article

\title{
Hydration Properties of Portland Cement Paste with Boron Gangue
}

\author{
Quan Zhao, ${ }^{1,2}$ Jianwei Tu, ${ }^{1}$ Weiwei Han $\left(D,{ }^{3}\right.$ Xi Wang, ${ }^{4}$ and Youzhi Chen ${ }^{5}$ \\ ${ }^{1}$ School of Civil Engineering and Architecture, Wuhan University of Technology, Wuhan, Hubei 430070, China \\ ${ }^{2}$ School of Civil Engineering, Nanyang Institute of Technology, Nanyang, Henan 473000, China \\ ${ }^{3}$ School of Engineering Management and Real Estate, Henan University of Economics and Law, Zhengzhou, \\ Henan 450000, China \\ ${ }^{4}$ Engineering Management, Henan Technical College of Construction, Zhengzhou, Henan 450000, China \\ ${ }^{5}$ School of Materials Science and Engineering, Wuhan University of Technology, Wuhan, Hubei 430070, China
}

Correspondence should be addressed to Weiwei Han; hww0059@163.com

Received 11 November 2019; Revised 18 January 2020; Accepted 4 February 2020; Published 16 March 2020

Academic Editor: Fernando Lusquiños

Copyright (c) 2020 Quan Zhao et al. This is an open access article distributed under the Creative Commons Attribution License, which permits unrestricted use, distribution, and reproduction in any medium, provided the original work is properly cited.

In order to prepare a good radiation shielding concrete with a proper setting time and a high strength, the hydration properties of cement with boron gangue were investigated by the methods of $\mathrm{XRD}$, isothermal microcalorimetry, TG/DSC, and FTIR. The results demonstrated that it was mainly related to the insoluble matter $\mathrm{CaB}_{2} \mathrm{O}_{4} \cdot 4 \mathrm{H}_{2} \mathrm{O}$ and $\mathrm{Ca}_{(}\left(\mathrm{H}_{2} \mathrm{BO}_{3}\right)_{2} \cdot 4 \mathrm{H}_{2} \mathrm{O}$ that boron gangue could severely inhibit the cement hydration. Boron gangue made a significant retardation on Portland cement hydration with the form of $\mathrm{BO}_{3}{ }^{3-}$ and $\mathrm{BO}_{4}{ }^{5-}$, which caused an obvious retardation of $\mathrm{C}_{3} \mathrm{~A}$ and $\mathrm{C}_{3} \mathrm{~S}$ hydration with an insoluble coat and a low solubility of calcium ion in the solution. Therefore, it is important and necessary to take into consideration the chemistry of borates in aqueous and the kind of cement-based or cementitious materials used for radiation shielding concrete with boron or boron compounds, especially for the materials with a high content of $\mathrm{C}_{3} \mathrm{~A}$ and $\mathrm{C}_{3} \mathrm{~S}$.

\section{Introduction}

The nuclear powder was clean with a low cost compared with other systems based on fossil fuels. However, radiation leakage from nuclear powder stations made a huge casualties and financial and environmental damages [1-3], like Chernobyl and Fukushima. Radiation was defined as the emission and transmission of atomic energy by electromagnetic waves or particles in vacuum and had significant hazards to living organisms. $X_{-}, \alpha_{-}, \beta$-, and $\gamma$-rays that were known as ionized radiation can become important threats for living organisms if required precautions were not taken, which could cause biological, chemical, and physical changes in living organisms. The most important and effective way of preventing the radiation hazard was shielding. Concrete was the most commonly used shield material as it was inexpensive and adaptable for any construction design.

Boron was a nonmetal element that was present in nature in many kinds of minerals and in a lot of industrial products of public use. Boron or boron compounds, as important raw materials, were widely used in various industries, especially nuclear powder industry [4-7]. They could increase the neutron shielding effectiveness of concretes due to its very high neutron absorption cross section, lower the costs of cement production, and were ecologically beneficial. However, boron usually caused serious retardation and a low early strength of concrete [8], which finally led to many problems and prevented the development of radiation shielding concrete. In order to make this better, many researches had been done and showed that the significant retardation of boron on concrete was related to the alkaline environment of hydrating cement system and hardened cement [9], or calcium hydroxide precipitation [10], or a coat with little insolubility $[11,12]$, and other objects. However, for now, the mechanism of boron and boron compounds on cementitious materials had not been thoroughly confirmed. 
Fortunately, it could be seen that the negative effects of boron on cement and concrete were usually made by $\mathrm{B}_{2} \mathrm{O}_{3}$ or in terms of $\mathrm{B}_{2} \mathrm{O}_{3}$, and most of the reports partly showed that the retardation of boron could be mainly related to the $\mathrm{C}_{3} \mathrm{~A}$ and $\mathrm{C}_{3} \mathrm{~S}$ hydration $[13,14]$. And the researches about the effect of $\mathrm{B}_{2} \mathrm{O}_{3}$ on cement hydration were rarely seen or reported. Therefore, in order to prepare a good radiation shielding concrete with a proper setting time and a high strength, the hydration properties of pure cement paste with 5.26 wt $\%$ boron gangue $\left(\mathrm{B}_{2} \mathrm{O}_{3}\right)$ [15] and the effects on the hydration of $\mathrm{C}_{3} \mathrm{~A}$ and $\mathrm{C}_{3} \mathrm{~S}$ were performed in this study. The mechanism of boron on cement hydration was also investigated by the methods of X-ray diffraction (XRD), isothermal microcalorimetry, thermogravimetric analysis (TG/DSC), and Fourier transformation infrared spectrometer (FTIR).

\section{Experimental Program}

2.1. Materials. Ordinary Portland cement (OPC) P. I. 42.5 (Table 1) was manufactured by Huaxin Cement Co. Ltd., Ezhou, Hubei, China. $\mathrm{C}_{3} \mathrm{~A}$ was prepared by chemosynthesis of a well-blended mixture of analytical grade $\mathrm{CaCO}_{3}$ and $\mathrm{Al}_{2} \mathrm{O}_{3}$ at $1380^{\circ} \mathrm{C}$. The synthesised product was analysed by XRD and cubic $\mathrm{Ca}_{3} \mathrm{Al}_{2} \mathrm{O}_{6}\left(\mathrm{C}_{3} \mathrm{~A}\right)$ phase was detected (Figure 1) with a specific surface area of $350 \mathrm{~m}^{2} / \mathrm{kg}$ which was determined by Blaine's method. The free lime content and insoluble residue were $0.27 \mathrm{wt} \%$ and $0.10 \mathrm{wt} \%$, respectively. $\mathrm{C}_{3} \mathrm{~S}$ was synthesised by chemosynthesis of a well-blended mixture of analytical grade $\mathrm{CaCO}_{3}$ and $\mathrm{SiO}_{2}$ at $1500^{\circ} \mathrm{C}$. The synthesised product was monoclinic $\mathrm{Ca}_{3} \mathrm{SiO}_{5}\left(\mathrm{C}_{3} \mathrm{~S}\right)$ phase (Figure 1) with a specific surface area of $410 \mathrm{~m} 2 / \mathrm{kg}$, and free lime content is less than $0.10 \mathrm{wt} \%$. Boron gangue $\left(\mathrm{B}_{2} \mathrm{O}_{3}\right)$, a kind of white powder, was obtained by the online shop (Xingsheng Scientific material, Taobao). Its purity is $99.9999 \%$, and its density is $1800 \mathrm{~kg} / \mathrm{m}^{3}$. Boron gangue was introduced to the cement paste as supplementary cementitious material (SCM) and deionized water was used for all pastes.

2.2. Specimens. Cement paste sample with water/cement ratio of 0.40 was prepared (Table 2 ). Cube-shaped samples $(40 \mathrm{~mm} \times 40 \mathrm{~mm} \times 40 \mathrm{~mm})$ were cast in steel molds and cured in standard conditions (temperature $20 \pm 1^{\circ} \mathrm{C}$, humidity $\geq 95 \%$ ). The samples were removed from the molds after $1 \mathrm{~d}$ and then cured in standard conditions. And, on the basis of the content of $\mathrm{C}_{3} \mathrm{~A}$ and $\mathrm{C}_{3} \mathrm{~S}$ in clinker or cement (Table 1), in order to avoid possible heterogeneities in the mixture and decrease the concentration gradients at the interface between solid and aqueous phase, another four paste samples were prepared with a high $w / c$ (water-cementitious ratio) (Table 3 ).

2.3. Methods. The tests were performed at the required ages ( $3 \mathrm{~d}, 7 \mathrm{~d}$, and $28 \mathrm{~d}$ ). The compressive strength is obtained by an automated breaking and compression resistance tester (WYA-300, Wuxi Xiyi Building Materials Instrument Factory, China); the $\mathrm{pH}$ value and the chemically combined water of hydrated cement paste were determined separately by a digital pH meter (putting $5 \mathrm{~g}$ hydrated cement paste powder
TABLE 1: Component of OPC.

\begin{tabular}{lcccc}
\hline Component & $\mathrm{C}_{3} \mathrm{~A}$ & $\mathrm{C}_{4} \mathrm{AF}$ & $\mathrm{C}_{3} \mathrm{~S}$ & $\mathrm{C}_{2} \mathrm{~S}$ \\
\hline Content, \% & 7.62 & 9.80 & 65.83 & 10.43 \\
\hline
\end{tabular}

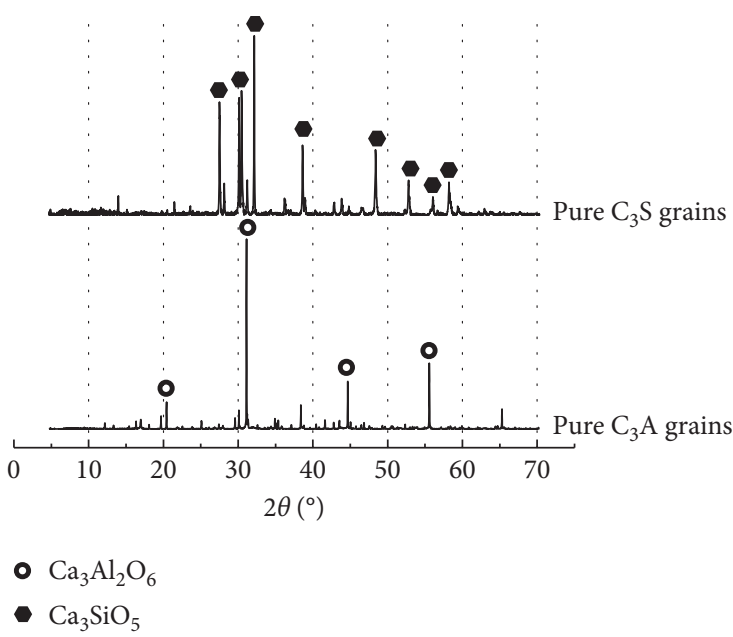

Figure 1: XRD patterns of $\mathrm{C}_{3} \mathrm{~A}$ and $\mathrm{C}_{3} \mathrm{~S}$.

TABle 2: Mix of cement pastes.

\begin{tabular}{lcc}
\hline & $\mathrm{A} 1$ & $\mathrm{~A} 2$ \\
\hline Cement, g & 600.0 & 570.0 \\
Boron gangue, g & 0.0 & 30.0 \\
Water, g & 240.0 & 240.0 \\
\hline
\end{tabular}

TABle 3: Mix of $\mathrm{C}_{3} \mathrm{~A}$ and $\mathrm{C}_{3} \mathrm{~S}$ pastes.

\begin{tabular}{lcccc}
\hline & $\mathrm{B} 1$ & $\mathrm{~B} 2$ & $\mathrm{C} 1$ & $\mathrm{C} 2$ \\
\hline $\mathrm{C}_{3} \mathrm{~A}, \mathrm{~g}$ & 10.0 & 10.0 & 0.0 & 0.0 \\
$\mathrm{C}_{3} \mathrm{~S}, \mathrm{~g}$ & 0.0 & 0.0 & 10.0 & 10.0 \\
Boron gangue, g & 0.0 & 7.0 & 0.0 & 0.8 \\
Water, g & 207.2 & 207.2 & 207.2 & 207.2 \\
\hline
\end{tabular}

(size: $\leq 75 \mu \mathrm{m}$ ) into a cup with $50 \mathrm{ml}$ distilled water and testing the $\mathrm{pH}$ value of the supernatant slurry by the meter after $2 \mathrm{~h}$ ) and vice the loss on ignition[16]; the mineralogical compositions of the hydrated cement paste, $\mathrm{C}_{3} \mathrm{~A}$ and $\mathrm{C}_{3} \mathrm{~S}$ pastes, were performed by X-ray diffraction (XRD) (D8 Advance, Bruker AXS Corporation, Germany) with a scan rate of $1^{\circ}$ per min; TA instruments (Discovery TGA, Waters Corporation, USA) at a $10^{\circ} \mathrm{C} \mathrm{min}^{-1}$ heating rate from room temperature to $850^{\circ} \mathrm{C}$ are performed and Fourier transformation infrared spectrometer (FTIR) (Nicolet 6700, Thermo Electron Scientific Instruments, USA) with a frequency range of $4000-399 \mathrm{~cm}^{-1}$ is used. In order to study the situation of hydrated products changing with temperature, isothermal microcalorimetry (C80, Setaram company, France) of hydration system is performed under a nitrogen atmosphere.

\section{Results and Discussions}

3.1. Setting Time and $p H$ Value. In Table 4, there are apparent differences between the cement paste without boron gangue (A1) and the cement paste with boron gangue (A2) on the 
TABLE 4: Setting time and $\mathrm{pH}$ value of cement paste.

\begin{tabular}{lccc}
\hline & & $\mathrm{A} 1$ & $\mathrm{~A} 2$ \\
\hline \multirow{2}{*}{ Setting time } & Initial & $3 \mathrm{~h} 40^{\prime}$ & $4 \mathrm{~h} 35^{\prime}$ \\
& Final & $5 \mathrm{~h} 10^{\prime}$ & $9 \mathrm{~h} 25^{\prime}$ \\
\hline \multirow{3}{*}{$\mathrm{pH}$ value } & $3 \mathrm{~d}$ & 12.38 & 9.21 \\
& $7 \mathrm{~d}$ & 12.42 & 10.08 \\
& $28 \mathrm{~d}$ & 12.59 & 10.60 \\
\hline
\end{tabular}

setting time (testing method seen in BS EN 196-3: 2005) and $\mathrm{pH}$ value. The initial setting time and final setting time of cement paste with boron gangue are $55 \mathrm{~min}$ and $4 \mathrm{~h}, 15 \mathrm{~min}$ longer than that of the cement paste without boron gangue, respectively. The $\mathrm{pH}$ value of cement paste with boron gangue is 2 to 3 smaller than that of the cement paste without boron gangue at the same age and this decreases with the increasing age. The cement hydration is retarded by boron gangue added.

When boron gangue is added to cement paste, an insoluble coat on cement grains' surfaces that prevents cement hydration will be produced. And combined with the effect of the reaction between boric acid and $\mathrm{Ca}(\mathrm{OH})_{2}$ (formulas (1) and (2)), the formation of portlandite nucleation is severely prevented; hence, there is more less portlandite crystal nucleus in the solution to supersaturation and crystallization $[10,17]$.

$$
\begin{gathered}
\mathrm{B}_{2} \mathrm{O}_{3}+3 \mathrm{H}_{2} \mathrm{O}=2 \mathrm{H}_{3} \mathrm{BO}_{3} \\
x \mathrm{H}_{3} \mathrm{BO}_{3}+y \mathrm{Ca}(\mathrm{OH})_{2}=\mathrm{Ca}_{y} \mathrm{~B}_{x} \mathrm{O}_{1.5 x+y}+(1.5 x+y) \mathrm{H}_{2} \mathrm{O}
\end{gathered}
$$

Then, the setting of cement paste is retarded with boron gangue added based on the analyses $[10,18]$. With a retardation from boron gangue, there are a lot of unhydrated cement grains in the cement paste with boron gangue so that the content of cement hydration products, especially $\mathrm{Ca}(\mathrm{OH})_{2}$, will be smaller than that of the cement paste without boron gangue. As a consequence, the $\mathrm{pH}$ value of hydrated cement paste with boron gangue is smaller than that of the hydrated cement paste without boron gangue at the same age because of the negative effect of the reaction between boric acid and $\mathrm{Ca}(\mathrm{OH})_{2}$ [19].

\subsection{Chemically Combined Water and Compressive Strength.} As Figures 2 and 3 depict, the chemically combined water content and compressive strength increase continuously with the age of hydration. However, the chemically combined water content and compressive strength of hydrated cement paste with boron gangue (A2) are $4.32 \%(3 \mathrm{~d}), 5.80 \%$ $(7 \mathrm{~d})$, and $6.65 \%(28 \mathrm{~d})$ and $1.8(3 \mathrm{~d}), 2.8(7 \mathrm{~d})$, and $6.6(28 \mathrm{~d})$, respectively, which are less $50 \%$ than that of the hydrated cement paste without boron gangue (A1, the blank) at the same age.

Generally, the increase in strength of hydrated cement paste is mainly attributed to the formation and latter accumulation of the hydration products which act as binding centers among the remaining unhydrated parts of the cement grains [20]. When both cement and boron gangue are

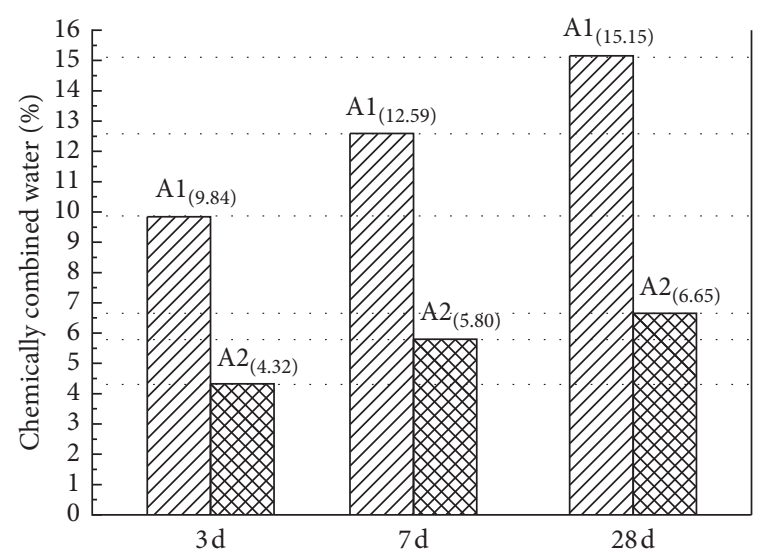

A1-Blank

A2-Boron gangue

Figure 2: Chemically combined water of hydrated cement paste.

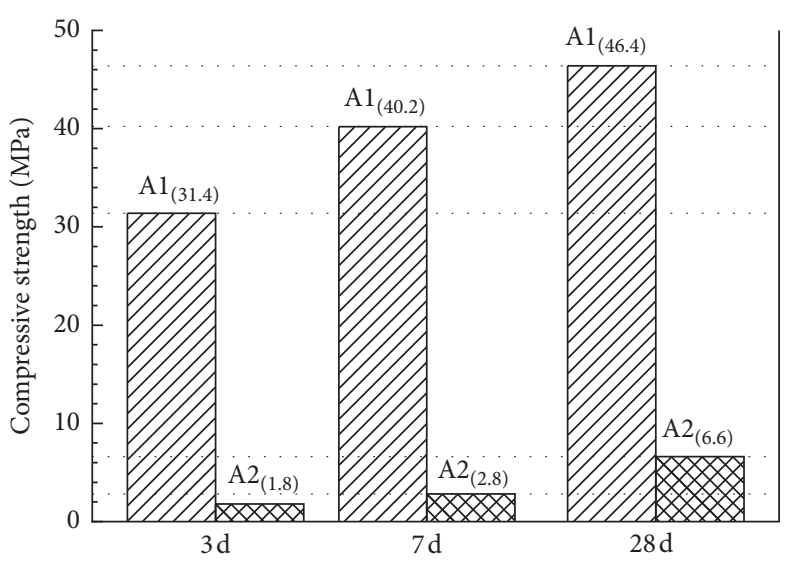

A1-Blank

A2-Boron gangue

FIGURE 3: Compressive strength of hydrated cement paste.

mixed with water, the cement hydration is severely retarded; there are a lot of anhydrous cements in the hydration system and the content of cement hydration products is very small, which causes the chemically combined water content to be less than that of the hydrated cement paste without boron gangue at the same age. Because there are a few cement hydration products in the hydrated cement paste with boron gangue, they cannot provide the strength for hydrated cement paste as a skeleton; a lot of unhydrated cement grains are not covered or connected by them. And then, the binding force between adjacent particles or groups is very weak, so it cannot provide high strength $[16,20]$. Finally, the chemically combined water content and compressive strength of hydrated cement paste with boron gangue are smaller than that of the hydrated cement paste without boron gangue at the same age.

3.3. Isothermal Microcalorimetry and XRD, TG/DSC, and FTIR. In Figure 4, there are significant differences between mineralogical compositions of hydrated cement paste with 


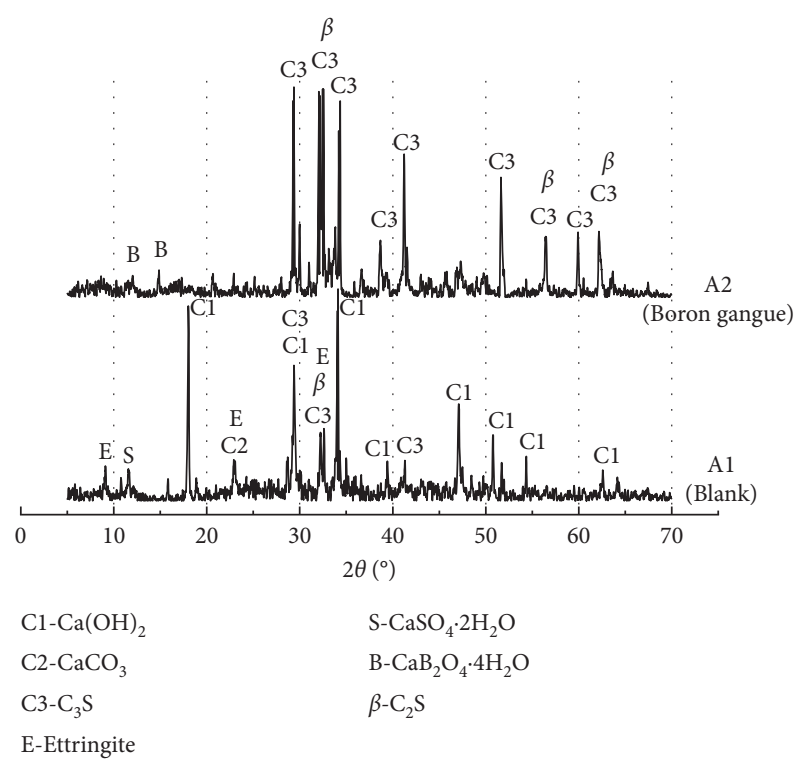

FIGURE 4: XRD patterns of hydrated cement paste for $28 \mathrm{~d}$.

A2 and without boron gangue A1. Compared to the hydrated cement paste with boron gangue (A2), only a little $\mathrm{CaB}_{2} \mathrm{O}_{4} \cdot 4 \mathrm{H}_{2} \mathrm{O}$ and a lot of $\mathrm{C}_{3} \mathrm{~S}$ and $\mathrm{C}_{2} \mathrm{~S}$ (that are anhydrous cement) are found. And for A2, the peak of ettringite that are usually observed in hydration phases in Portland cement hydration is very low. This demonstrates that boron gangue severely prevents the cement hydration, which is similar to the results of $\mathrm{pH}$ value, chemically combined water content, and compressive strength.

In Figures 5 and 6, there seems to be the same situation about the change of heat flow of the cement paste with and without boron gangue. However, combined with the results of heat flow and heat evolution, there are some big differences between cement paste without boron gangue (A1) and cement paste with boron gangue (A2). During the several hours of cement hydration, the heat flow and heat evolution of cement paste with boron gangue are higher than that of cement paste without boron gangue, which is mainly related to a lot of heat released from the dissolution of boron gangue within several hours [21-23]. And, with the increase of hydration time, the heat flow and heat evolution of cement paste without boron gangue is the bigger one. The whole heat evolution $(0 \sim 72 \mathrm{~h})$ of cement paste with boron gangue is $24.98 \%$ of the whole heat evolution $(0 \sim 72 \mathrm{~h})$ of cement paste without boron gangue, which demonstrates that the cement hydration is severely retarded by boron gangue added.

As for the periods $0-\mathrm{a}$ and $0-\mathrm{b}$, based on the reports of Pacewska and Wilińska [24] and Bost et al. [25] about the cement hydration stage division, when cement and boron gangue are mixed with water, the calcium ion concentration in the solution will be decreased by the reaction between boron gangue and $\mathrm{Ca}(\mathrm{OH})_{2}$ (formula (3)). The calcium ion in the solution from the dissolution of $\mathrm{CaB}_{2} \mathrm{O}_{4}$ may be disadvantageous to the precipitation and crystallization of calcium hydroxide, which will cause a lower cement hydration rate. Meanwhile, $\mathrm{CaB}_{2} \mathrm{O}_{4}$, a kind of insoluble material, will prevent the $\mathrm{C}_{3} \mathrm{~A}$ hydration as well as gypsum.
Therefore, during 0 -a period, the hydration of cement paste with boron gangue is retarded with a lower calcium hydroxide content in the solution and the retardation of $\mathrm{C}_{3} \mathrm{~A}$ hydration.

$$
2 \mathrm{H}_{3} \mathrm{BO}_{3}+\mathrm{Ca}(\mathrm{OH})_{2}=\mathrm{CaB}_{2} \mathrm{O}_{4}+4 \mathrm{H}_{2} \mathrm{O}
$$

with respect to the period a-c of the blank (A1, cement paste without boron gangue), there is not a sharp peak in the heat flow curve but a flat peak like arch bridge (b-d). The heat flow of cement paste without boron gangue is bigger than that of cement paste with boron gangue. At the same time, combining with heat evolution curve, the heat evolution of cement paste with boron gangue is $26.71 \%$ of the heat evolution of cement paste without boron gangue, which demonstrates that $\mathrm{C}_{3} \mathrm{~S}$ hydration of cement paste with boron gangue is severely prevented by boron gangue [19]. Thus, the content of C-S-H and $\mathrm{Ca}(\mathrm{OH})_{2}$ in the hydration system of cement paste with boron gangue will be lower than that of the cement paste without boron gangue.

During the hydration stage, the heat flow will get slow and the cement paste hydration will be gradually controlled by the diffusion of ions participating in the hydration. Combined with the results of heat flow and heat evolution of cement paste with boron gangue, they are lower than that of cement paste without boron gangue, which means that the hydration of cement paste with boron gangue is still severely prevented by boron gangue. Therefore, during the whole cement hydration, it is always prevented with boron gangue added, especially for $\mathrm{C}_{3} \mathrm{~A}$ hydration and $\mathrm{C}_{3} \mathrm{~S}$ hydration. Finally, the heat flow (except for initial 1 to $2 \mathrm{~h}$ ) and heat evolution (except for initial $5 \mathrm{~h}$ ) of cement paste with boron gangue are lower than that of the cement paste without boron gangue. They are consistent with the results of setting time (Table 4) and chemically combined water content (Figure 2).

However, heat measurement alone may not be sufficient to accurately determine the ultimate value, especially if it is measured only up to 21 days. The data from DTA (Differential Thermal Analysis)/TGA (Thermal Gravimetric Analysis) can be used to determine the ultimate quantity, since they were obtained up to 180-210 days [26]. Figure 7 shows the TG/ DSC curves of cement hydration products on $28 \mathrm{~d}$. According to the literature reports $[16,20]$, the degree of hydration is calculated by dividing the mass between $23^{\circ} \mathrm{C}$ and $550^{\circ} \mathrm{C}$ by the maximum theoretical nonevaporable water (or chemically bound water, $w_{b}$ ), as presented in formula (4), and the mass loss at approximately $450-500^{\circ} \mathrm{C}$ is used to measure the $\mathrm{Ca}(\mathrm{OH})_{2}$ content as presented in the following [26]:

$$
\text { Degree of hydration }=\frac{\text { Mass loss }\left(23-550^{\circ} \mathrm{C}\right)}{w_{\mathrm{b}}} \text {, }
$$

$$
\begin{aligned}
\mathrm{Ca}(\mathrm{OH})_{2} \text { content }(\text { wt } \%)= & \text { Mass loss }\left(450-500^{\circ} \mathrm{C}\right) \\
& \times \frac{\text { Molar Mass of } \mathrm{Ca}(\mathrm{OH})_{2}}{\text { Molar Mass of } \mathrm{H}_{2} \mathrm{O}} .
\end{aligned}
$$

In Figure 8, compared to the blank (cement paste without boron gangue), the degree of hydration of cement paste with boron gangue is 0.16 , which is about $20 \%$ of the 


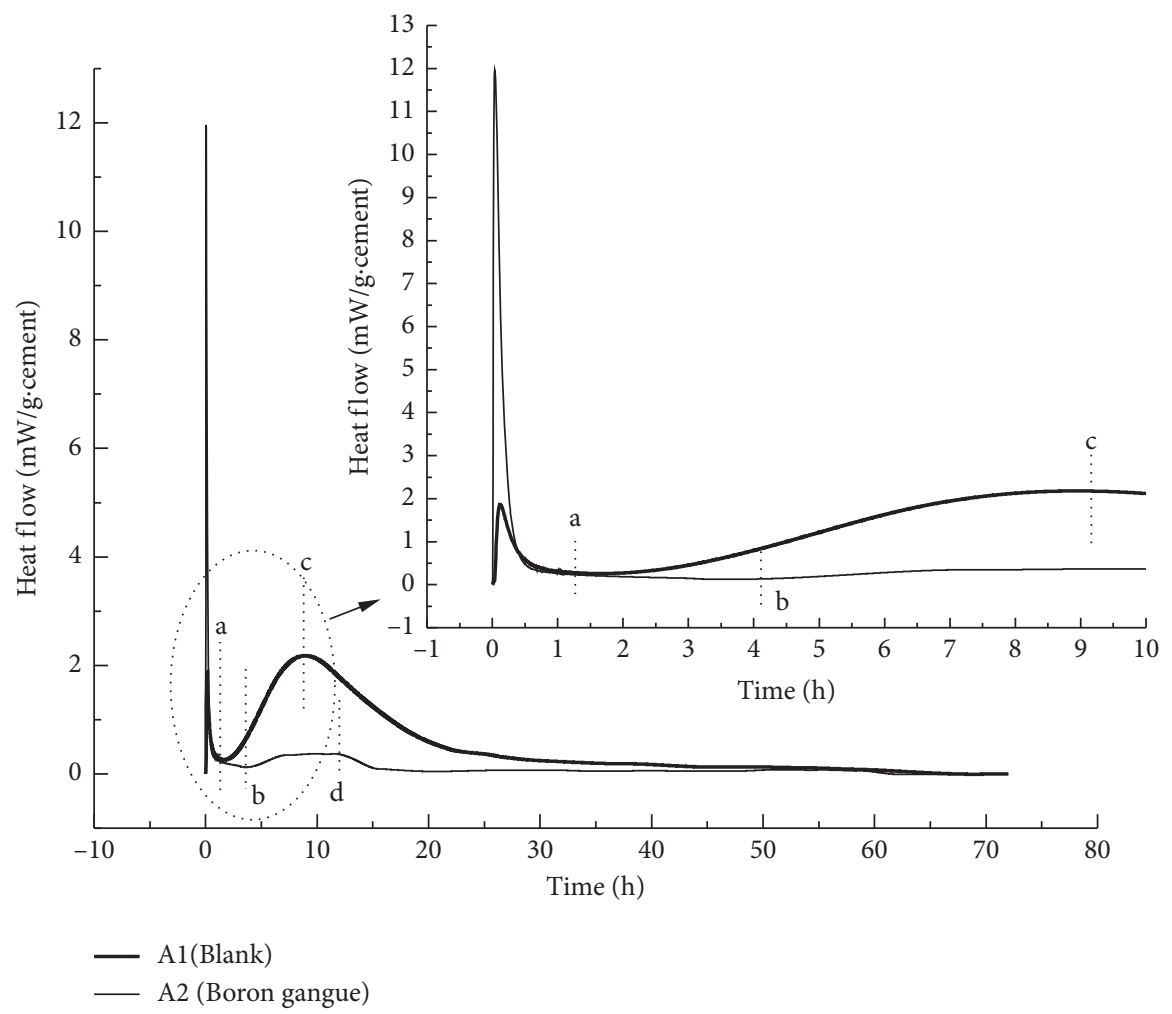

FIgUre 5: Heat flow over time during cement hydration.

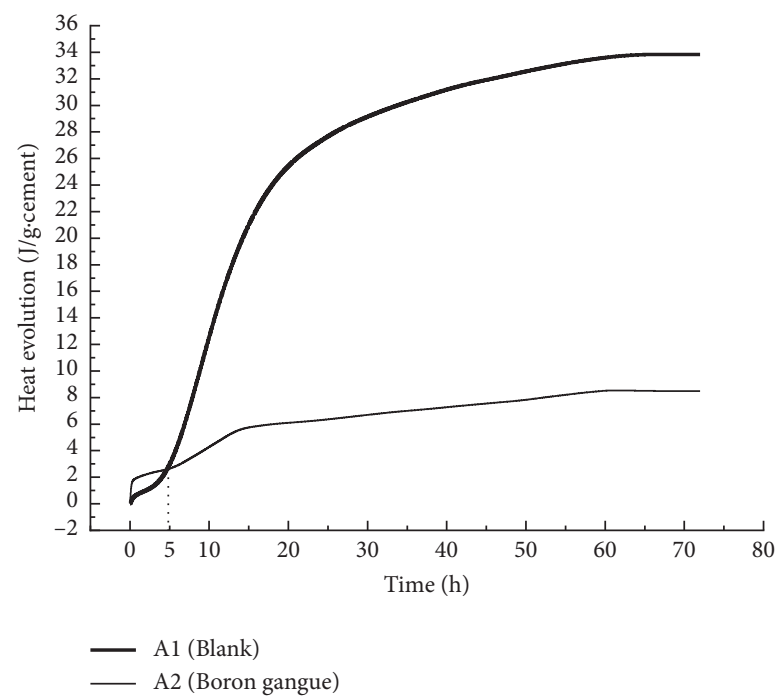

FIgURE 6: Heat evolution over time during cement hydration.

blank. It is obvious that cement hydration is severely suppressed by boron gangue added. As a result, the heat flow and heat evolution over time and the content of hydration products in hydration system are decreased, and the setting time is retarded, which agree with the results of the XRD (Figure 4), heat flow and heat evolution over time (Figures 5 and 6), chemically combined water content (Figure 2), and the setting time (Table 4). The $\mathrm{Ca}(\mathrm{OH})_{2}$ content of cement paste with boron gangue is about $7.8 \%$ of the cement paste without boron gangue. The decrease of its content means that the hydration system has a low $\mathrm{pH}$ value, which will cause an unsteadiness and even decomposition of the main hydration products such as C-S-H gel and ettringite [27]. Then, the compressive strength and chemically combined water content (Figure 2) and the intensity of the main hydration products (Figure 4) are decreased.

Figures 9 and 10 show the diffraction patterns of $\mathrm{C}_{3} \mathrm{~A}$ and $\mathrm{C}_{3} \mathrm{~S}$ with and without boron gangue, and there are significant differences about the mineralogical compositions of $\mathrm{C}_{3} \mathrm{~A}$ or $\mathrm{C}_{3} \mathrm{~S}$ with and without boron gangue. Based on the 


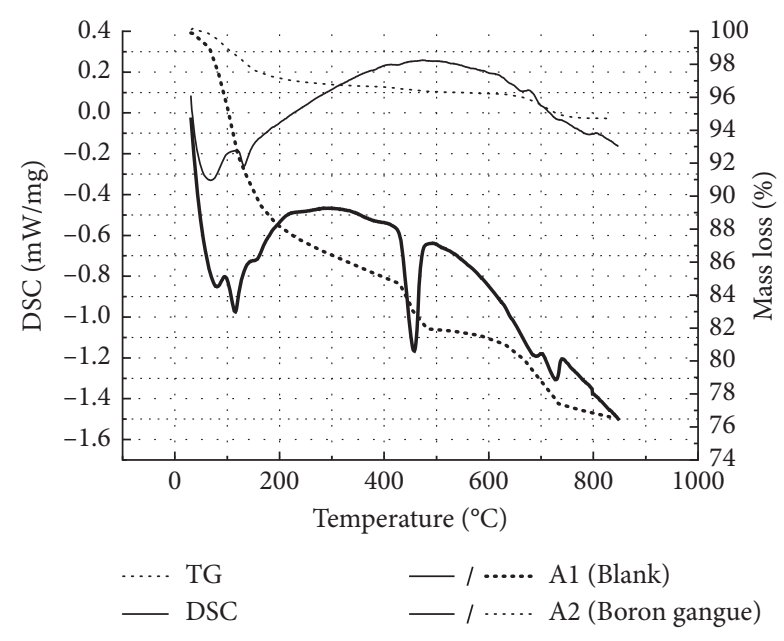

FIgURE 7: TG and DSC curves of cement hydration products on $28 \mathrm{~d}$.

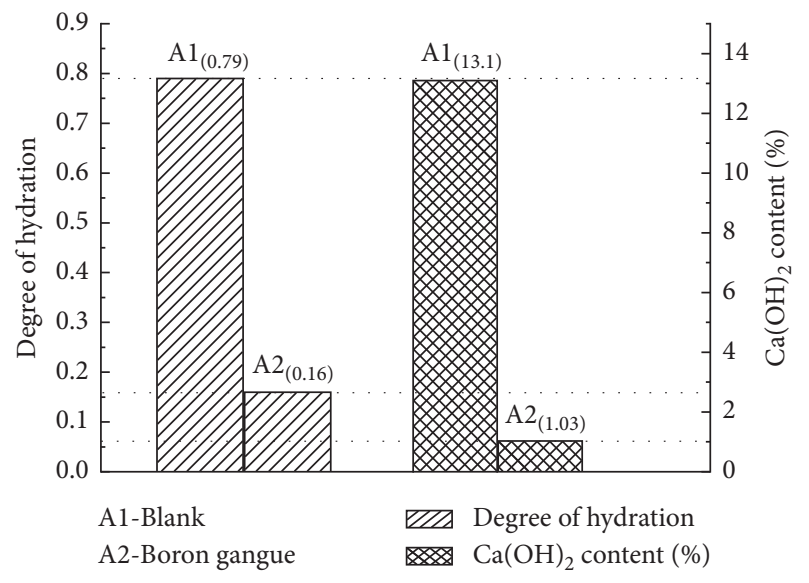

Figure 8: Degree of hydration and $\mathrm{Ca}(\mathrm{OH}) 2$ content of cement paste on $28 \mathrm{~d}$.

reports of pure $\mathrm{C}_{3} \mathrm{~A}$ hydration [28] and pure $\mathrm{C}_{3} \mathrm{~S}$ hydration [29], the hydration process can be described in five steps (Figure 11).

(1) The mineralogical compositions of pure $\mathrm{C}_{3} \mathrm{~A}$ grains are very similar to that of the $\mathrm{C}_{3} \mathrm{~A}$ with boron gangue after $7 \mathrm{~d}$, which means that the $\mathrm{C}_{3} \mathrm{~A}$ hydration is significantly retarded by boron gangue. It is consistent with the analysis about the results of Figures 5 and 6 . Both boron and aluminum belong to a main group, the chemical activity of boron is very similar to aluminum. But boron is a higher nonmetal element so the ability to combine with anions is stronger than that of aluminum. Boron will decrease the solubility of aluminum in the solution where concentration is very important for the $\mathrm{C}_{3} \mathrm{~A}$ hydration and the formation of $3 \mathrm{CaO} \cdot \mathrm{Al}_{2} \mathrm{O}_{3} \cdot 6 \mathrm{H}_{2} \mathrm{O}$ $\left(\mathrm{C}_{3} \mathrm{AH}_{6}\right)$ and even ettringite [30]. In addition, due to an insoluble coat $\left(\mathrm{CaB}_{2} \mathrm{O}_{4} \cdot 4 \mathrm{H}_{2} \mathrm{O}\right)$ on the $\mathrm{C}_{3} \mathrm{~A}$ surface produced by the reaction between calcium ion around $\mathrm{C}_{3} \mathrm{~A}$ grains and boron gangue in the solution which prevents $\mathrm{C}_{3} \mathrm{~A}$ grains contacting with more water or

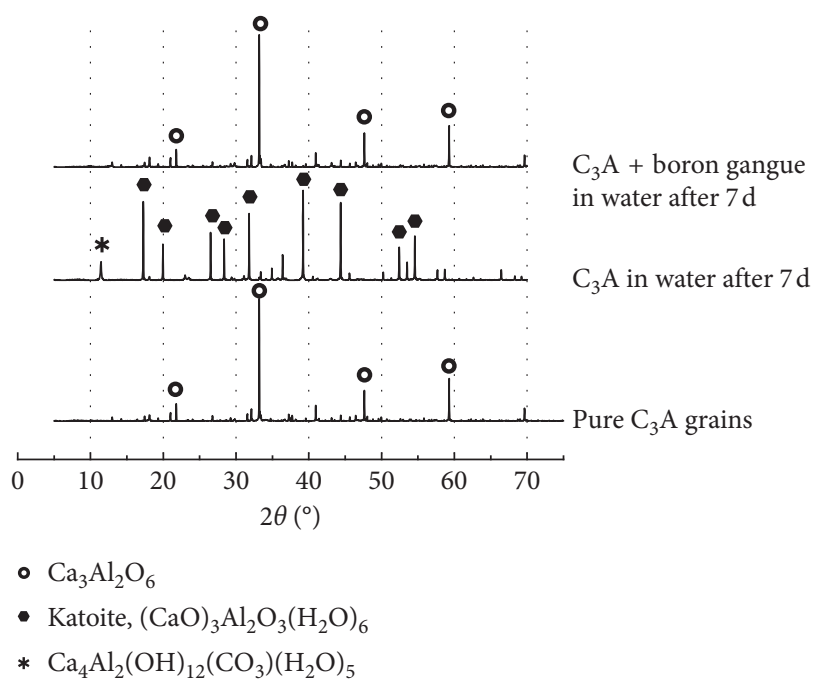

Figure 9: XRD patterns of different $\mathrm{C}_{3} \mathrm{~A}$ hydration system.

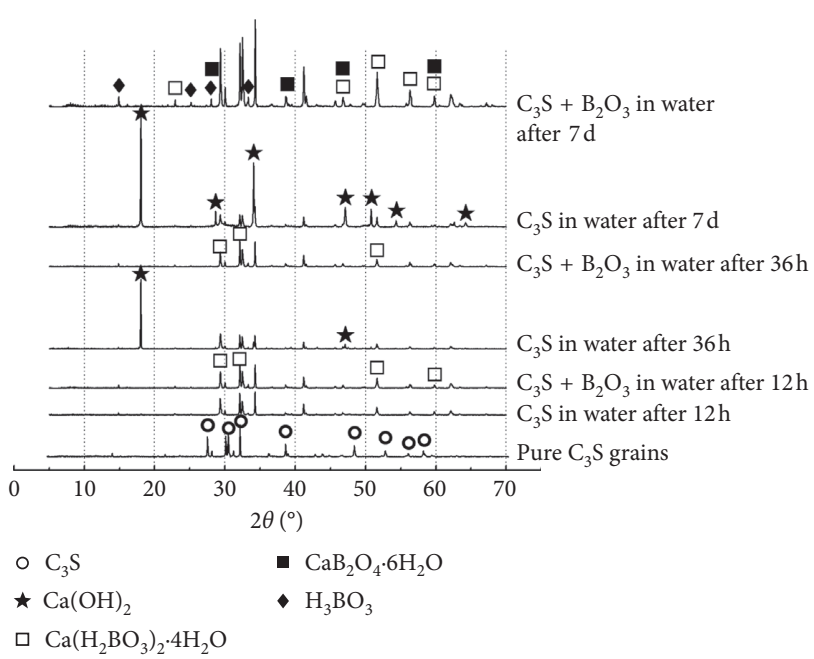

Figure 10: XRD patterns of different $\mathrm{C}_{3} \mathrm{~S}$ hydration system.

gypsum, $\mathrm{C}_{3} \mathrm{~A}$ will finally get a lower hydration degree, which is in agreement with the results of XRD (Figures 4 and 9) and heat flow and heat evolution of hydrated cement paste with boron gangue (Figures 5 and 6).

(2) According to the reports of Bensted [10], the setting properties of cement paste is mainly in charge of calcium hydroxide precipitation. Combined with the results of XRD patterns of $\mathrm{C}_{3} \mathrm{~S}$ (Figure 10), when boron gangue is added to $\mathrm{C}_{3} \mathrm{~S}$ hydration system, the calcium hydroxide (one of the most important and representative hydration products of $\mathrm{C}_{3} \mathrm{~S}$ hydration) will be consumed with a reaction by boron gangue.

$$
\begin{gathered}
\mathrm{C}_{3} \mathrm{~S}+\mathrm{H}_{2} \mathrm{O} \longrightarrow \mathrm{C}-\mathrm{S}-\mathrm{H}+\mathrm{Ca}(\mathrm{OH})_{2} \\
\mathrm{Ca}(\mathrm{OH})_{2}+\mathrm{B}_{2} \mathrm{O}_{3}+5 \mathrm{H}_{2} \mathrm{O}=\mathrm{Ca}\left(\mathrm{H}_{2} \mathrm{BO}_{3}\right)_{2} \cdot 4 \mathrm{H}_{2} \mathrm{O}
\end{gathered}
$$

and there is no $\mathrm{Ca}(\mathrm{OH})_{2}$ and a little $\mathrm{CaB}_{2} \mathrm{O}_{4} \cdot 6 \mathrm{H}_{2} \mathrm{O}$ for $\mathrm{C}_{3} \mathrm{~S}$ hydration with boron gangue after $7 \mathrm{~d}$, which may be mainly 


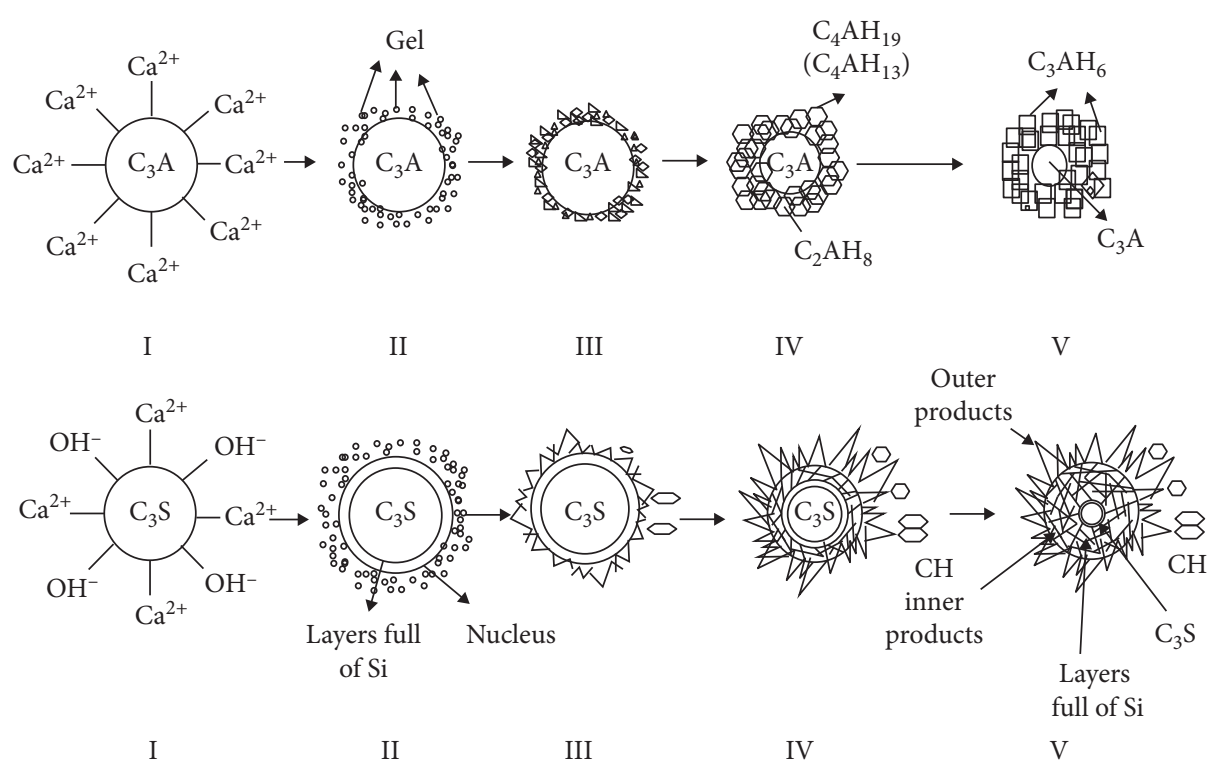

Figure 11: Schematic diagram of $\mathrm{C}_{3} \mathrm{~A}$ and $\mathrm{C}_{3} \mathrm{~S}$ hydration process.

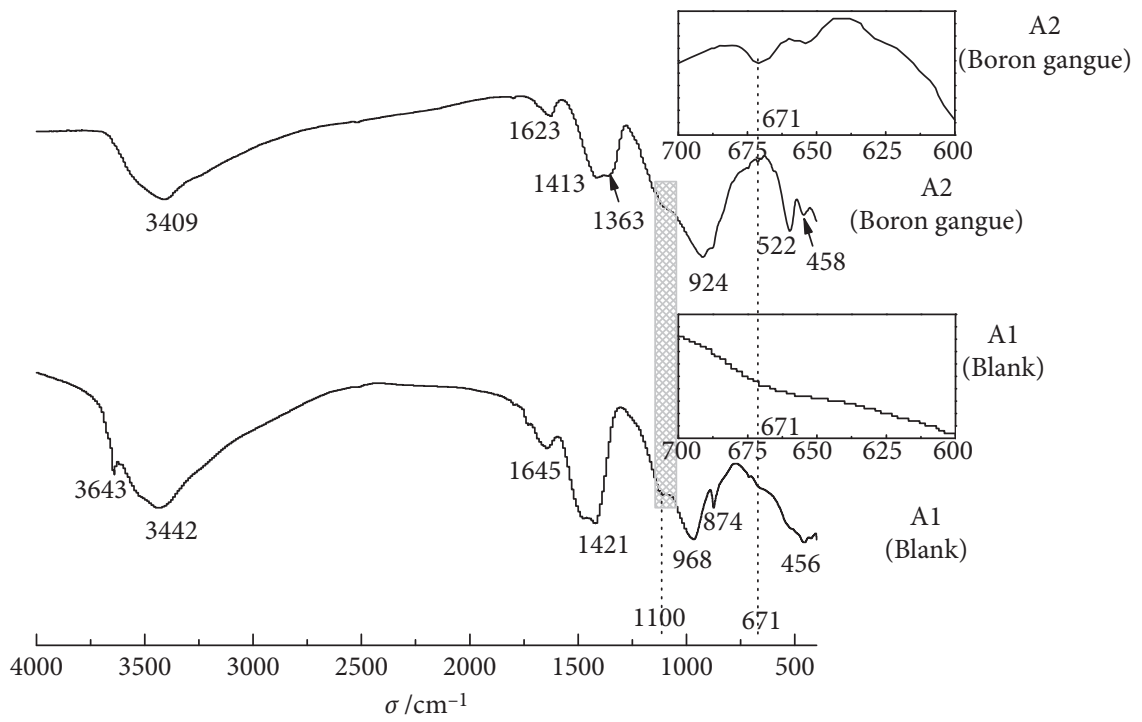

FIgURE 12: FTIR spectra of hydrated cement paste on $28 \mathrm{~d}$.

related to a high boron gangue concentration [10]. More boron gangue in the solution needs more calcium hydration and may generate many particle groups containing boron ion, and these particle groups are put together with a group of structure $\mathrm{CaB}_{2} \mathrm{O}_{4} \cdot 6 \mathrm{H}_{2} \mathrm{O}$ [31]. On the other hand, a lower concentration of calcium hydration in the solution means a lower alkalinity ( $\mathrm{pH}$ value), which can in turn cause an unsteadiness and even decomposition of hydration products such as C-S-H gel and ettringite [27] that make a significant role in the setting and mechanical properties of cement paste. A poor behaviour of $\mathrm{C}-\mathrm{S}-\mathrm{H}$ and ettringite will cause a negative effect on the hydration of cement paste, which coincides with the results of a longer setting time, a lower chemically combined water content, and compressive strength.

Therefore, the cement hydration is retarded because both $\mathrm{C}_{3} \mathrm{~A}$ hydration and $\mathrm{C}_{3} \mathrm{~S}$ hydration are suppressed by boron gangue with an insoluble coat and a lower calcium hydration concentration in the solution.

According to the literature reports [32], bonds in the region of $1200-400 \mathrm{~cm}^{-1}$ are often regarded as fingerprint of cement hydration, which was very important for evaluating cement hydration. In Figure 12, FTIR spectra of A1 (blank, hydrated cement paste without boron gangue) and A2 (hydrated cement paste with boron gangue) can be observed and their curves are taken on a similar tendency except for their wavenumbers (A1 with 7, A2 with 6), whose changes in cement hydration could reflect changes of some silicate structures. Compared with the hydrated cement paste without boron gangue, FTIR spectra of hydrated cement paste with boron gangue do not have wave around $3646 \mathrm{~cm}^{-1}$ that was the typical bands of hydroxyl of $\mathrm{Ca}(\mathrm{OH})_{2}$ [32], which partly indicates that the content of $\mathrm{Ca}(\mathrm{OH})_{2}$ 
crystals is severely decreased by boron gangue added in the system. And this is in agreement with a lower $\mathrm{pH}$ value of hydrated cement paste with boron gangue and the results of $\mathrm{XRD}$ of cement paste and $\mathrm{C}_{3} \mathrm{~S}$ with boron gangue. The wave at $3442 \mathrm{~cm}^{-1}$ is moved to a lower one $\left(3411 \mathrm{~cm}^{-1}\right)$ and the bond that is related to the vibration of hydroxyl is changed from sharp to flat, which result in the decrease of the chemically combined water content in molecule. There is a "shoulder" at $1363 \mathrm{~cm}^{-1}$, which is a typical vibration of changing angle in the plane of $\mathrm{BO} 3-3$ with its 3 ligand. The waves area in $1110-1140 \mathrm{~cm}^{-1}$ becomes flat, which means the decrease of AFt and AFm content which are usually regarded as matrix minerals (that are useful for strength development) and it finally results in the retardation of cement hydration. Meanwhile, as for hydrated cement paste with boron gangue, there is no wave at $1100 \mathrm{~cm}^{-1}$, which indicates that the content of SO $2-4$ in the solution is decreased because of boron gangue and shows that the compressive strength of hydrated cement paste with boron gangue is lower than that of the hydrated cement paste without boron gangue. In addition, with respect to the FTIR spectra of hydrated cement paste with boron gangue, there is a wave at $671 \mathrm{~cm}^{-1}$, which is related to the bending of outside of the plane of BO $5-4$ with its 4 ligand. As a result, when boron gangue is added to cement paste, the concentration of $\mathrm{Ca}(\mathrm{OH})_{2}$ and the solubilities of SO $2-4$ in the solution can be decreased by the boron gangue with the form of $\mathrm{BO} 3-3$ and $\mathrm{BO} 5-4$.

\section{Conclusions}

In this paper, the hydration properties of Portland cement paste with boron gangue are investigated and the following conclusions are drawn.

(1) Boron gangue can be solidified by Portland cement paste with the form of $\mathrm{CaB}_{2} \mathrm{O}_{4} \cdot 4 \mathrm{H}_{2} \mathrm{O}$ and $\mathrm{Ca}\left(\mathrm{H}_{2} \mathrm{BO}_{3}\right)_{2} \cdot 4 \mathrm{H}_{2} \mathrm{O}$. C-S-H, AFt, and AFm that are the main hydration products of Portland cement have little effects on the solidification of boron gangue.

(2) Boron gangue can make a significant retardation on Portland cement hydration with the results of a long setting time and a low compressive strength. These obvious negative effects of boron gangue are mainly related to the retardation of $\mathrm{C}_{3} \mathrm{~A}$ and $\mathrm{C}_{3} \mathrm{~S}$ hydration, which are suppressed by an insoluble coat and a low solubility of calcium ion in the solution. Therefore, it is necessary to take into consideration the kind of cement-based or cementitious materials used for the recovery of wastes containing boron, especially for the cement with a high content of $\mathrm{C}_{3} \mathrm{~A}$ and $\mathrm{C}_{3} \mathrm{~S}$.

\section{Data Availability}

All the data in this study are in shcool computer, it is difficult to obtain them in time because I am trapped at home due to the epidemic. All data included in this study are available upon request by contact in the future, and I will upload the data as soon as the epidemic is resolved.

\section{Conflicts of Interest}

The authors declare that they have no conflicts of interest.

\section{Acknowledgments}

This work was financially supported by the National Natural Science Foundation of China (no. 51478372), National "Twelfth Five-Year" Plan for Science and Technology Support Development Program of China (no. 2014BAB15B01), the Science and Technology Project of Henan Province (no. 182102310797), and the Key Research Projects of Henan Higher Education Institutions (no.20B560003).

\section{References}

[1] M. M. Abu-Khader, "Recent advances in nuclear power: a review," Progress in Nuclear Energy, vol. 51, no. 2, pp. 225235, 2009.

[2] L. Gagnon, C. Bélanger, and Y. Uchiyama, "Life-cycle assessment of electricity generation options: the status of research in year 2001," Energy Policy, vol. 30, no. 14, pp. 1267-1278, 2002.

[3] R. E. H. Sims, H.-H. Rogner, and K. Gregory, "Carbon emission and mitigation cost comparisons between fossil fuel, nuclear and renewable energy resources for electricity generation," Energy Policy, vol. 31, no. 13, pp. 1315-1326, 2003.

[4] R. G. Jaeger, E. P. Blizard, A. B. Chilton et al., Engineering Compendium on Radiation Shielding: Volume 2: Shielding Materials, pp. 164-339, Springer, New York, NY, USA, 1975.

[5] W. A. Kansouh, A. El-Sayed Adbo, and R. M. Megahid, Radiation Shielding Properties of Dolomite and Ilmenite concretes, International Nuclear Information System, in Proceedings of 4th Conference and Workshop on Cyclotrones and Applications, International Nuclear Information System, Cairo, Egypt, pp. 17-21, February 2011.

[6] Y. Verzilov, K. Ochiai, A. Klix et al., "Non-destructive analysis of impurities in beryllium, affecting evaluation of the tritium breeding ratio," Journal of Nuclear Materials, vol. 329-333, pp. 1337-1341, 2004.

[7] S. J. Shiao and C. M. Tsai, "The study on improving Masonry cement for solidification of borate waste," Radioactive Waste Manage and the Nuclear Fuel Cycle, vol. 11, pp. 319-331, 1989.

[8] A. Olgun, T. Kavas, Y. Erdogan, and G. Once, "Physicochemical characteristics of chemically activated cement containing boron," Building and Environment, vol. 42, no. 6, pp. 2384-2395, 2007.

[9] Q. Sun, J. Li, and J. Wang, "Effect of borate concentration on solidification of radioactive wastes by different cements," Nuclear Engineering and Design, vol. 241, no. 10, pp. 43414345, 2011.

[10] J. Bensted, I. C. Callaghan, and A. Lepre, "Comparative study of the efficiency of various borate compounds as set-retarders of class G oilwell cement," Cement and Concrete Research, vol. 21, no. 4, pp. 663-668, 1991.

[11] M. H. Kharita, S. Yousef, and M. Alnassar, "Review on the addition of boron compounds to radiation shielding concrete," Progress in Nuclear Energy, vol. 53, no. 2, pp. 207-211, 2011.

[12] K. Yang, C. Zhang, Y. Guo et al., "Study on retarding the set of sulphoaluminate cement," Journal of the Chinese Ceramic Society, vol. 30, pp. 155-160, 2002. 
[13] A. Palomo and J. I. López dela Fuente, "Alkali-activated cementitous materials: alternative matrices for the immobilisation of hazardous wastes," Cement and Concrete Research, vol. 33, no. 2, pp. 281-288, 2003.

[14] A. Cuesta, E. R. Losilla, M. A. G. Aranda, J. Sanz, and Á. G. De la Torre, "Reactive belite stabilization mechanisms by boron-bearing dopants," Cement and Concrete Research, vol. 42, no. 4, pp. 598-606, 2012.

[15] J. Callan Edwin and O. Henrie James, Concrete for Radiation Shielding, Literary Licensing, Whitefish, MT, USA, 2012.

[16] M. Heikal and N. S. Ibrahim, "Hydration, microstructure and phase composition of composite cements containing nanoclay," Construction and Building Materials, vol. 112, pp. 1927,2016

[17] N. Kabay, I. Yılmaz, S. Yamac et al., "Removal and recovery of boron from geothermal wastewater by selective ion exchange resins. I. laboratory tests," Reactive and Functional Polymers, vol. 60, pp. 163-170, 2004.

[18] A. Peschard, A. Govin, P. Grosseau, B. Guilhot, and R. Guyonnet, "Effect of polysaccharides on the hydration of cement paste at early ages," Cement and Concrete Research, vol. 34, no. 11, pp. 2153-2158, 2004.

[19] R. P. Salvador, S. H. P. Cavalaro, I. Segura, A. D. Figueiredo, and J. Pérez, "Early age hydration of cement pastes with alkaline and alkali-free accelerators for sprayed concrete," Construction and Building Materials, vol. 111, pp. 386-398, 2016.

[20] M. Aqel and D. K. Panesar, "Hydration kinetics and compressive strength of steam-cured cement pastes and mortars containing limestone filler," Construction and Building $\mathrm{Ma}$ terials, vol. 113, pp. 359-368, 2016.

[21] S. Yao, Q. W. Hu, M. D. Wang et al., "Progress in the effects of different admixtures on the properties of sulphoaluminate cement," Guangdong Building Materials, vol. 9, pp. 14-16, 2010, in Chinese.

[22] X. H. Sun, "Research and development of calcium borate and its application," Modern Chemical Industry, vol. 11, pp. 24-26, 1996, in Chinese.

[23] J. S. Zhang, Z. F. Hui, F. Gao et al., "Influence of crystal stabilization on the strength of high B-lite sulphate-aluminate cement," Journal of Shenyang Architectural and Civil Engineering University, vol. 21, pp. 38-42, 2005, in Chinese.

[24] B. Pacewska and I. Wilińska, "Hydration of cement composites containing large amount of waste materials," Procedia Engineering, vol. 57, pp. 53-62, 2013.

[25] P. Bost, M. Regnier, and M. Horgnies, "Comparison of the accelerating effect of various additions on the early hydration of Portland cement," Construction and Building Materials, vol. 113, pp. 290-296, 2016.

[26] I. Pane and W. Hansen, "Investigation of blended cement hydration by isothermal calorimetry and thermal analysis," Cement and Concrete Research, vol. 35, no. 6, pp. 1155-1164, 2005.

[27] J. Ma, Z. Zhou, F. Yang et al., "Impact of $\mathrm{pH}$ value on cement hydration properties," Cement Engineering, vol. 27, no. 5, pp. 13-15, 2013, in Chinese.

[28] A. Quennoz and K. L. Scrivener, "Hydration of $\mathrm{C}_{3} \mathrm{~A}$-gypsum systems," Cement and Concrete Research, vol. 42, no. 7, pp. 1032-1041, 2012.

[29] L. P. Singh, S. K. Bhattacharyya, S. P. Shah, G. Mishra, and U. Sharma, "Studies on early stage hydration of tricalcium silicate incorporating silica nanoparticles: part II," Construction and Building Materials, vol. 102, pp. 943-949, 2016.
[30] J. Pourchez, P. Grosseau, and B. Ruot, "Current understanding of cellulose ethers impact on the hydration of $\mathrm{C}_{3} \mathrm{~A}$ and $\mathrm{C}_{3} \mathrm{~A}$-sulphate systems," Cement and Concrete Research, vol. 39, no. 8, pp. 664-669, 2009.

[31] E. H. Ezechi, M. H. Isa, S. R. Kutty et al., Boron Recovery, Application and Economic Significance: A Review, , pp. 1-6, National Postgraduate Conference, 2011.

[32] S. B. Eskander, T. A. Bayoumi, and H. M. Saleh, "Performance of aged cement-polymer composite immobilizing borate waste simulates during flooding scenarios," Journal of Nuclear Materials, vol. 420, no. 1-3, pp. 175-181, 2012. 